\title{
A PHENOLIC ACID AND ITS ANTIOXIDANT ACTIVITY FROM STEM BARK OF CHLOROFORM FRACTION OF SYZYGIUM LITTORALE(BLUME) AMSHOFF (MYRTACEAE)
}

\section{SUATU ASAM FENOLIK DAN AKTIVITAS ANTIOXIDAN DARI FRAKSI KLOROFORM KULIT BATANG TUMBUHAN SYZYGIUM LITTORALE(BLUME) AMSHOFF (MYRTACEAE)}

\author{
Tukiran $^{1, *}$, Fitriyatul Mahmudah ${ }^{1}$, Nurul Hidayati $^{1}$, Kuniyoshi Shimizu $^{2}$ \\ ${ }^{1}$ Department of Chemistry, Faculty Mathematics and Natural Sciences, Surabaya State University, \\ Surabaya, Indonesia \\ ${ }^{2}$ Department of Forests and Forest Products Sciences, Faculty of Agriculture, Kyushu University, \\ Fukuoka, Japan \\ *email: btukiran@yahoo.com
}

Received 7 June 2016; Accepted 28 September 2016; Available online 29 November 2016

\begin{abstract}
This study describes the chemical investigations of Syzygiumlittorale (S.littorale), a plant belonging to the family Myrtaceae, and their antioxidant properties. As far, there is no study due to chemical investigations conducted to the plant either on leaves, fruits, stem bark or the others. The stem bark of S. littorale was extracted with organic solvent and the extracts were then fractionated and purified by using standard chromatographic techniques. The molecular structure of pure isolated pure compound was elucidated and established through extensive spectroscopic studies and by comparing with literature data and authentic sample. The dried and powdered stem bark of S. littorale was extracted with methanol and then partitioned by chloroform. Chromatographic (vacuum liquid chromatography and gravitational column chromatography) fractionation and purification of the chloroform soluble fraction that is always monitored by TLC yielded a pure isolated pure compound. The purified compound was then identified and justified as a phenolic acid i.e. gallic acid. This compound is found for the first time from this plant, although it has previously been found in other Syzygium species such as S. aromaticum, S. cumini, S. polyanthum, $S$. cordatum, etc. The chloroform fraction, isolated compound, and vitamin C showed very strong antioxidant activity against 2,2'-diphenyl-1-picrylhydrazyl (DPPH) with the $\mathrm{IC}_{50}$ value of $23.2 ; 7.5$; and $12.5 \mu \mathrm{g} / \mathrm{mL}$, respectively.
\end{abstract}

Keywords: chloroform fraction, DPPH, gallic acid, Syzygiumlittorale, vitamin C.

\section{ABSTRAK}

Penelitian ini menyajikan hasil penyelidikan kimia terhadap tumbuhan klampok alas/watu, Syzygiumlittorale (S. littorale), suatu tumbuhan yang termasuk family Myrtaceae dan sifat anti oksidannya. Sejauh ini, belum ada penelitian terkait dengan penyelidikan kimia yang dilakukan terhadap tumbuhan tersebut baik pada daun, buah, kulit batang atau bagian lainnya. Kulit batang tumbuhan $S$. littorale diekstraksi dengan pelarut organic dan selanjutnya ekstrak difraksinasi (diisolasi) dengan menggunakan teknik-teknik kromatografi yang standar. Struktur molekul dari senyawa murni hasil isolasi dielusidasi dan ditetapkan melalui kajian spektroskopi secara mendalam dan juga dilakukan dengan cara membandingkannya dengan data literature dan sampel asli. Serbuk kering kulit batang S. littorale diekstraksi dengan methanol dan kemudian dipartisi dengan kloroform. Isolasi terhadap fraksi kloroform melalui kromatografi cair vakum dan kromatografi kolom gravitasi yang selalu dimonitor dengan KLT menghasilkan suatu senyawa murni. Senyawa murni ini selanjutnya diidentifikasi dan dipastikan sebagai senyawa asam fenolik, yaitu asam galat. Diperolehnya asam galat dari tumbuhan $S$. littorale merupakan laporan penemuan untuk pertama kalinya, meskipun sebelumnya senyawa ini telah ditemukan pada tumbuhan Syzygium lainnya, seperti S. aromaticum, S. cumini, S. polyanthum, S. cordatum, dll. Fraksi 
kloroform, senyawa hasil isolasi dan vitamin $\mathrm{C}$ telah menunjukkan aktivitas antioksidan sangat kuat (aktif) terhadap DPPH dengan nilai $\mathrm{IC}_{50}$ masing-masing adalah 23,$2 ; 7,5 ; \mathrm{dan} 12,5 \mu \mathrm{g} / \mathrm{mL}$.

Kata Kunci: asam galat, DPPH, fraksi kloroform, Syzygiumlittorale, vitamin C.

\section{INTRODUCTION}

Syzygium, the genus of flowering plants, is one of the important genus in Myrtaceae family, widely presented in the tropical and sub-tropical region of the world, with the greatest diversity of species taking place in South East Asia such as Indonesia, Malaysia and also in East India. On the basis of literature study, phytochemical studies on Syzygiumspecies have led to the identification and isolation of main compounds such as phenolic compounds (eugenol and eugenol acetate found in S. aromaticum (Alma, Murat, Siegfrie, \& Hubert, 2007). Also, the other phenolic compounds namely flavonoids had been obtained from $S$. polyanthum (Wight) Walp leaves (Har \& Ismail, 2012), S. aquem leaf (Manaharan, David, Hwee,\& Uma, 2012), and from S.alternifolium Walp. Leaf (Komuraiah et al., 2014). On the other hand, several Syzygiumspecies reported have antioxidant properties are $S$. cumini leaves (Ruan, Liang, \& Yi, 2008), S. polyanthum (Wight) Walp leaves (Har \& Ismail, 2012), S. aqueum (Osman, Afidah, Norhafizah, \& Nornaemah, 2009) and $S$. lanceolatum (Muthumperumal, Nadarajan, Arun, \& Swamy, 2016).

Syzygiumlittorale that has many synonyms with Eugenia littorale (Blume) Meijer Drees, Eugenia subglauca Koord. \& Valeston and Jambosalittorale Blumeis a species in the Myrtaceae, native to Indonesia with common name "klampok". Local people call it as 'klampok watu' or 'klampok alas'. This species is a wild species, mostly found along the riverbanks, e.g. Resort Seroja. The wood can be used as building materials since it is long lasting and strong (Ariyanti, Rony, Lia, \& Deden, 2012). Based on the literature data, no information about the total phenolic contents, antioxidant and other bioactivity potentials of the medicinal organic compounds in the stem bark of $S$. littorale that have been reported so far. Therefore, we are interested strongly to investigate them especially for phenolic contents and their antioxidant bioactivity from the stem bark extract of this plant. The present study however, reports the finding of gallic acid for the first time from the chloroform fraction of the stem bark of $S$. littorale.

\section{EXPERIMENTAL SECTION}

\section{Materials}

\section{Chemicals and plant materials}

Isolated compound from the stem bark of $S$. littorale, 2,2-diphenyl-1picrylhydrazyl (DPPH), vitamin C (vit.C, ascorbic acid, as antioxidant standard) were purchased from Merck (Germany) and Sigma Aldrich (USA), hexane, chloroform, ethyl acetate, methanol and silica gel used were obtained from local sources and were of analytical grade (Grade AR). The stem bark of S. littorale (c.a. $25 \mathrm{~kg}$ ) was collected from a local area in Bojonegoro, East Java, Indonesia in December 2014. The identification of the plant was performed by the staff of Herbarium-LIPI, Purwodadi, East Java, Indonesia. A voucher sample is kept in the Herbarium of LIPI with Identification No. 0116/IPH.06/HM/I/2015, January 10, 2015.

\section{Equipment and instruments}

The equipment used to do extraction and fractionation (isolation) are filter paper, Buchner funnel, Hirsch funnel, Erlenmeyer flask, pippet, spatula, measuring glass, vials, containers, separating funnel, and vacuum rotary evaporator type BUCHI Rotavapor R-215. The equipment used to measure melting point of an isolate is Fisher Scientific. Whereas, chromatographic techniques 
used to isolate phenolic compounds from chloroform fraction included Vacuum Liquid Chromatography (VLC) (using silica gel 60, 0.040-0.063 mm), Gravitational Column Chromatography (GCC) (silica gel 60, 0,063-0,200 mm and $0,200-0,500 \mathrm{~mm}$ or $70-230 \mathrm{mesh}$ ASTM).

TLC analyses were carried out on silica gel 60 F254 chromaplates with the developing solvent systems. Checking the homogeneity of the compounds were made by TLC on Kieselgel gel 60 F254 pre-coated sheets (E.Merck) and the spots were detected by exposure to UV-lamp at $254 \mathrm{~nm}$ or $366 \mathrm{~nm}$.

Some instruments needed to identify and characterize an isolate included spectrophotometer FTIR-8400S and spectrophotometer UV-1800 (SHIMADZU). The ${ }^{1} \mathrm{H}$ NMR spectra were recorded with a Bruker DRX-600 NMR
Spectrometer $(600 \mathrm{MHz}, \quad$ CD3OD $)$ instrument and the ${ }^{13} \mathrm{C}$ NMR spectra were obtained with the same instrument at 150 $\mathrm{MHz}$ in CD3OD. Chemical shifts are given in $\delta(\mathrm{ppm})$ values relative to those of the solvent signal [CD3OD $\left(\delta_{\mathrm{H}} 3.30 ; \delta_{\mathrm{C}}\right.$ 49.0)] on the tetramethylsilane (Sigma) scale.

\section{Procedure}

\section{Extraction and isolation}

The fresh stem bark of $S$. littorale (c.a. $25 \mathrm{~kg}$ ) was washed with under tap water and dried under sunlight for one week. It was then ground to be smooth powder as much as $9.5 \mathrm{~kg}$. The dried powder of plant was macerated with methanol at room temperature for 24 hours. The mixture was then filtered and the filtrate obtained was concentrated to be crude extract (967.6 g).

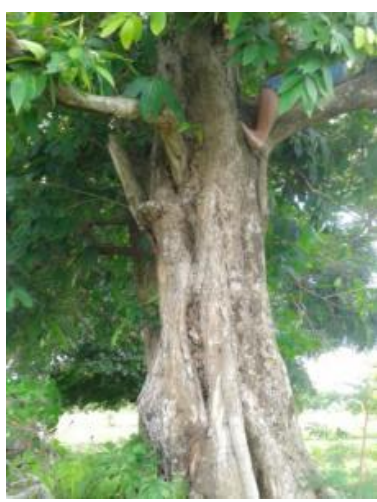

Syzygium littorale
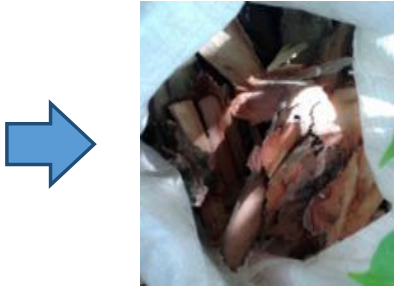

The fresh stem bark of S. littoreale

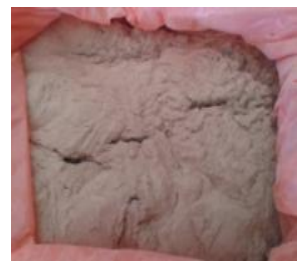

The dried-powdered of $S$. littorale
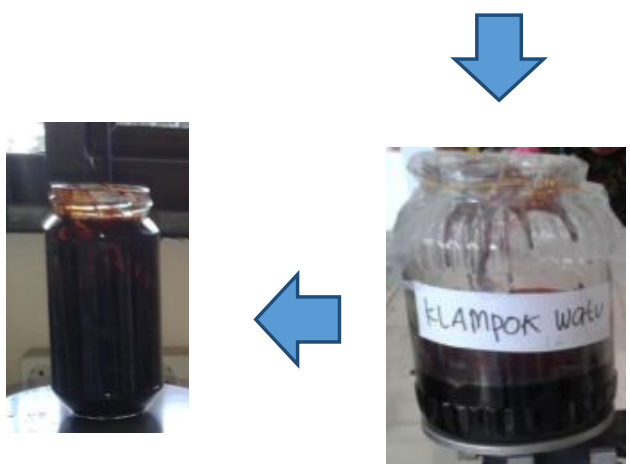

Methanol extract

Chloroform fraction

Gallic acid

Colorless needle crystal

Figure 1. Isolation process to find gallic acid from chloroform fraction of Syzygiumlittorale stem bark 
The extract was then suspended in methanol and defatted with hexane to yield two layers. The upper part (hexane soluble parts) was evaporated to gain hexane extracts $(15.044 \mathrm{~g})$ and the lower part (methanol soluble parts) is called residue. By using the same manner, the residue was suspended in methanol and defatted with chloroform to yield two layers as well. The lower layer (chloroform soluble parts) was also evaporated to obtain chloroform fractions (107.787 g).

A portion of chloroform fractions $(10 \mathrm{~g})$ was then chromatographed through VLC using hexane-ethyl acetate system (100: $0 \rightarrow 0$ : 100) to yield 43 fractions. The same way, it was also rechromatographed to the fractions for four times and called to be VLC-1, VLC-2, VLC-3, and VLC-4. Of these, fractions 17-20 of VLC-1, fractions 21-34 of VLC2 , fractions $18-30$ of VLC-3 and fractions 21-31 of VLC-4 were combined by TLC to yield $3 \mathrm{~g}$ (as fraction $\mathrm{B}$ ). Fraction $\mathrm{B}$ was then separated through GCC using eluent system (hexane: ethyl acetate $=4: 6$ ) to get 22 fractions. On the basis of TLC, the fractions can be grouped into three fractions (B1, B2 and B3). When observed on TLC plate, the fraction B2 was seemed to give simple chromatogram profile $(0.5$ g).

Finally, the fraction was then purified through GCC using eluent system (hexane: chloroform: methanol $=1: 8: 1$ ) to yield 59 fractions that can be combined into four fractions [B21 (1-13), B22 (1429), B23 (30-42), and B24 (43-59). The fraction B23 was allowed to evaporate at room temperature and yielded a colorless needle crystal $(50 \mathrm{mg})$ with $\mathrm{mp}$. 256-257 ${ }^{\circ} \mathrm{C}$. The crystal was then characterized by UV-Vis, FTIR, and NMR spectroscopies and by comparison with literature data and authentic sample (gallic acid) and determined its structure to be gallic acid. Extraction and isolation that had been carried out to find the isolate can be seen in Figure 1.

Free radical scavenging ability on 2,2diphenyl-1-picrylhydrazyl (DPPH)

In order to assess the scavenging ability of 2,2'-Diphenyl-1-picrylhydrazyl (DPPH), each test samples (the chloroform fraction or isolated compound or antioxidant standard (Vit. C) $(0.3 \mathrm{~mL}$ : $10,25,50,75$ and $100 \mu \mathrm{g} / \mathrm{mL}$ ) in methanol was mixed with methanol solution $(3 \mathrm{~mL})$ containing DPPH radicals $(0.004 \%, w / w)$. The mixture was shaken vigorously and left to stand for 30 minutes in the dark before measuring the absorbance at $515 \mathrm{~nm}$ against a blank (Braca et al., 2001) with slight modifications. Then, the scavenging ability (the percentage inhibition, I\%) was calculated using the following equation:

$$
\mathrm{I} \%=\left[\left(\mathrm{A}_{\text {blank }}-\mathrm{A}_{\text {sample }}\right) / \mathrm{A}_{\text {blank }}\right] \times 100
$$

Where $A_{\text {blank }}$ is the absorbance value of the control and $\mathrm{A}_{\text {sample }}$ is the absorbance value of the test samples (Khan, Khan, Sahreen, \& Ahmed, 2012). Percentage radical scavenging ability was plotted against the corresponding antioxidant substance concentration. The results were analyzed as $\mathrm{IC}_{50}$ values and were calculated by linear regression analysis of tests conducted in triplicates.

The equation for the line is used to obtain the $\mathrm{IC}_{50}$ value, which is defined as the amount of antioxidant substance required to scavenge $50 \%$ of free-radicals (DPPH) present in the assay system. On the other words, $\mathrm{IC}_{50}(50 \%$ inhibitory concentration) values were obtained through extrapolation from concentration of test samples necessary to scavange $50 \%$ of free-radicals (DPPH). A lower $\mathrm{IC}_{50}$ value indicates greater activity. $\mathrm{IC}_{50}<50$ $\mu \mathrm{g} / \mathrm{mL}$ is very active; $50 \mu \mathrm{g} / \mathrm{mL}<\mathrm{IC}_{50}<$ $100 \mu \mathrm{g} / \mathrm{mL}$ is active; $100 \mu \mathrm{g} / \mathrm{mL}<\mathrm{IC}_{50}<$ $200 \mu \mathrm{g} / \mathrm{mL}$ is moderately active; and $\mathrm{IC}_{50}$ $>200 \mu \mathrm{g} / \mathrm{mL}$ is not active (Reynertson, 2007). 


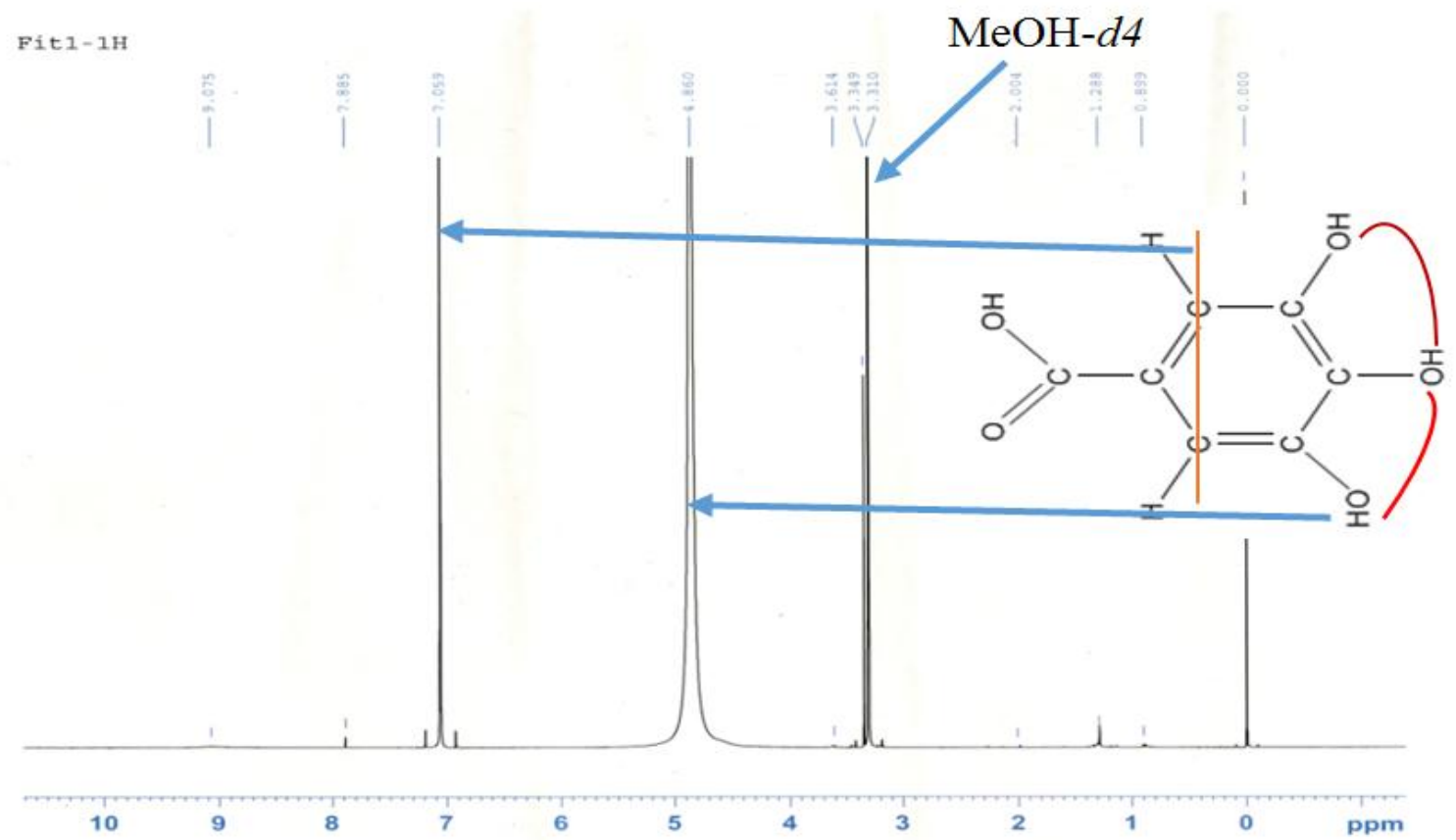

Figure 2. The H-NMR spectral data of isolated compound (gallic acid)

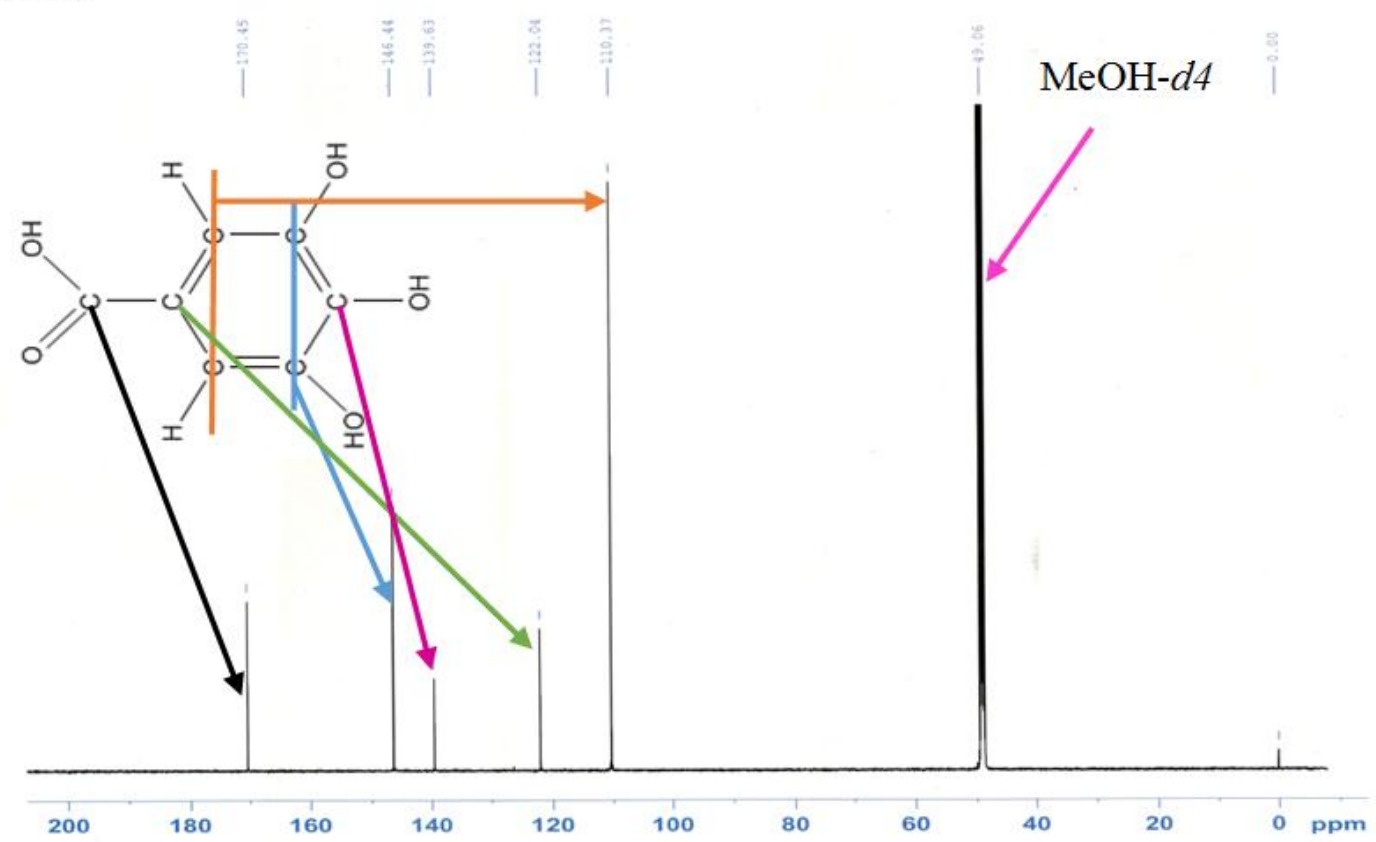

Figure 3. The C-NMR spectral data of isolated compound (gallic acid)

\section{RESULTS AND DISCUSSION}

\section{Structural Determination of The Isolated Compound}

Isolated compound was obtained as a colorless needle crystals $(50 \mathrm{mg})$ with mp. 256-257 ${ }^{\circ} \mathrm{C}$. The UV-Vis $(\mathrm{MeOH}$, $\left.\lambda_{\max }\right)$ spectrum of isolated compound showed maximum absorption at 216 and $271 \mathrm{~nm}$ indicating a phenolic compound. The IR spectrum of the isolated compound displayed absorption bands broadly at $3462-3013 \mathrm{~cm}^{-1}$ and at $1705 \mathrm{~cm}^{-1}$ indicating hydroxyl and carbonyl groups, respectively. The absorption bands at 1620, 1541, and $1450 \mathrm{~cm}^{-1}$ and 1265 , 1246, and $1208 \mathrm{~cm}^{-1}$ indicated the presence of benzene ring system and three -O-aryls directly attached to the benzene ring, respectively. The last absorption band at $702 \mathrm{~cm}^{-1}$ showed substituted benzene. 
The ${ }^{1} \mathrm{H}-\mathrm{NMR}$ spectrum $(600 \mathrm{MHz}$, $\mathrm{MeOH}-d 4$, ppm) of the isolated compound displayed the presence of an aromatic singlet at $\delta_{\mathrm{H}} 7.06(2 \mathrm{H}, \mathrm{s})$. The ${ }^{1} \mathrm{H}-\mathrm{NMR}$ spectrum of it also showed a broad singlet at $\delta_{\mathrm{H}}$ 4.86showed the presence of three aromatic hydroxyl groups (aryl-OH) as can be seen in Figure 2. The ${ }^{13} \mathrm{C}$-NMR spectrum $(150 \mathrm{MHz}, \mathrm{MeOH}-d 4$, ppm) of isolated compound displayed five carbon signals, one carbon signal at $\delta_{\mathrm{C}} 170.45$ confirming significantly for a carbonyl group, two carbon signals at $\delta_{\mathrm{C}} 110.37$ and 146.44 confirming as benzene ring attached at meta-hydrogen and metahydroxyl group, respectively. Finally, the rest carbon signals at $\delta_{\mathrm{C}} 139.63$ and 122.04 confirming as substituted benzene as shown in Figure 3.
When ${ }^{1} \mathrm{H}-$ and ${ }^{13} \mathrm{C}-\mathrm{NMR}$ spectra of the isolated compound were compared with those of gallic acid as reported in literature data (Hiranrat, 2010), it could be identical as shown in Table 1. Also, by comparing the IR data of the isolated compound with that of an authentic sample (gallic acid) as shown in Figure 4, it was confirmed as gallic acid. Needed to note that this is the first report of its occurrence in $S$. littorale, although it has previously been found in other Syzygium species such as $S$. cumini (Sikder et al., 2012) and $S$. Polyanthum (Har \& Ismail, 2012), etc.

Table 1: H- and C-NMR spectral data for the isolated compound and gallic acid

\begin{tabular}{ccccc}
\hline \multirow{2}{*}{ Position } & \multicolumn{2}{c}{$\begin{array}{c}\text { Isolated Compound } \\
\text { (MeOH-d4) }\end{array}$} & \multicolumn{2}{c}{$\begin{array}{c}\text { Gallic acid } \\
(\text { DMSO-d6) }\end{array}$} \\
\cline { 2 - 5 } & $\delta \mathrm{C}$ & $\delta \mathrm{H}$ & $\delta \mathrm{C}$ & $\delta \mathrm{H}$ \\
$(150 \mathrm{MHz})$ & $(600 \mathrm{MHz})$ & $(75 \mathrm{MHz})$ & $(300 \mathrm{MHz})$ \\
\hline 1 & 122.04 & - & 120.89 & - \\
$2(6)$ & 110.37 & $7.06(\mathrm{~s})$ & 109.16 & $6.90(\mathrm{~s})$ \\
$3(5)$ & 146.44 & - & 145.84 & - \\
4 & 139.63 & - & 138.43 & - \\
7 & 170.45 & - & 169.96 & - \\
\hline
\end{tabular}

${ }^{\mathrm{a}}$ Gallic acid compared was isolated Rhodomyrtus tomentosa (Hiranrat, 2010)

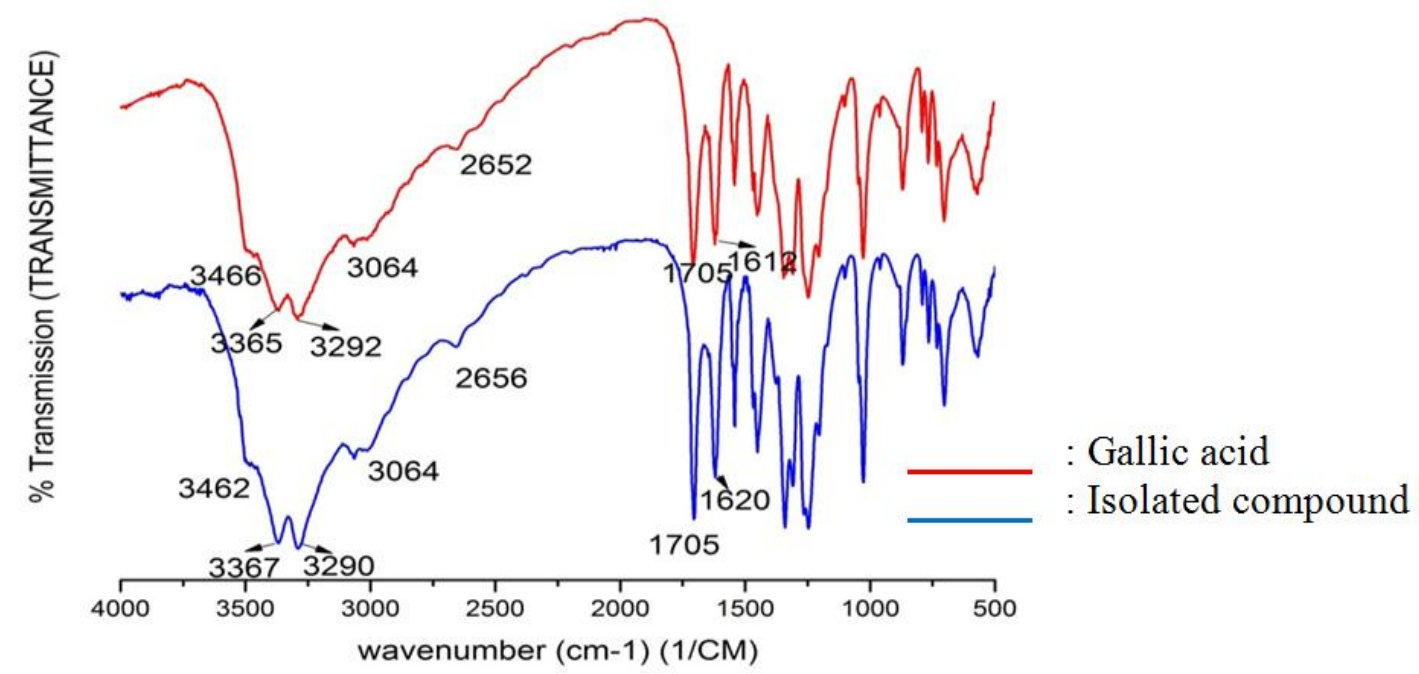

Figure 4. The comparison of IR spectral data of isolated compound and that of authentic sample (gallic acid) 


\section{DPPH free radical-scavenging assay}

In this paper, the free radicalscavenging activities of the tested samples including chloroform fraction, isolated compound from $S$. littorale and also vitamin $\mathrm{C}$ toward DPPH radical could be explained as follows.DPPH radical has been used frequently been used as a reactive hydrogen acceptor for the determination of radical scavenging activity of various natural and synthetic compounds. In this study, tested samples used (chloroform fraction, isolated compound and vitamin $\mathrm{C}$ ) can be natural and synthetic compounds. The $\mathrm{IC}_{50}$ value of an antioxidant can be defined as the concentration of antioxidant required for $50 \%$ scavenging of DPPH radical in the period of 30 minutes. After doing the free radical scavenging assay of tested samples, the $\mathrm{IC}_{50}$ values of them was determined to be $23.2 ; 7.5$; and 12.5 $\mu \mathrm{g} / \mathrm{mL}$, respectively. It can be declared that isolated compound showed a more effective hydrogen donating capacity $\left(\mathrm{IC}_{50}\right.$ $7.5 \mu \mathrm{g} / \mathrm{mL}$ ) than the chloroform fraction $\left(\mathrm{IC}_{50} 23.2 \mu \mathrm{g} / \mathrm{mL}\right)$ and vitamin $\mathrm{C}\left(\mathrm{IC}_{50}\right.$ $12.5 \mu \mathrm{g} / \mathrm{mL}$ ). But, vitamin $\mathrm{C}$ displayed a more effective hydrogen donating capacity than the chloroform fraction. The graphs showed percentage inhibition of chloroform fraction, isolated compound and vitamin $\mathrm{C}$ could be plotted and compared as shown in Figure 5.

It was observed that the regression equations of tested samples (chloroform fraction (CF), isolated compound (IC) and vitamin $\mathrm{C}$ (Vit. C)) and the good correlations of them are $\mathrm{y}=0.1545 \mathrm{x}+$ $46.421\left(\mathrm{R}^{2}=0.992\right), \mathrm{y}=0.1528 \mathrm{x}+48.850$ $\left(\mathrm{R}^{2}=0.993\right)$, and $\mathrm{y}=0.1570 \mathrm{x}+48.036$ $\left(\mathrm{R}^{2}=0.991\right)$ for $\mathrm{CF}$, IC, and Vit. C, respectively (as shown in Table 2). The free radical scavenging activity of the chloroform fraction was significantly related to its phenolic content $\left(\mathrm{R}_{\mathrm{DPPH}}=\right.$ 0.992) (Figure 5). The chloroform fraction exhibited the high radical scavenging activity because of the presence of phenolic compounds in the fraction such as gallic acid as isolated from the fraction. As reported that gallic acid (3,4,5-trihydroxybenzoic acid) represents a secondary metabolites found in large family of plant and possess natural antioxidant properties (PatrickIwuanyanwu, Onyeike, \& Adhikari, 2014). The high free radical scavenging ability of the fraction of $S$. littorale is also similar to the other Syzygium genera like $S$. cumini that might be responsible for this high antioxidant activity (Ruan, Liang, \& Yi, 2008).

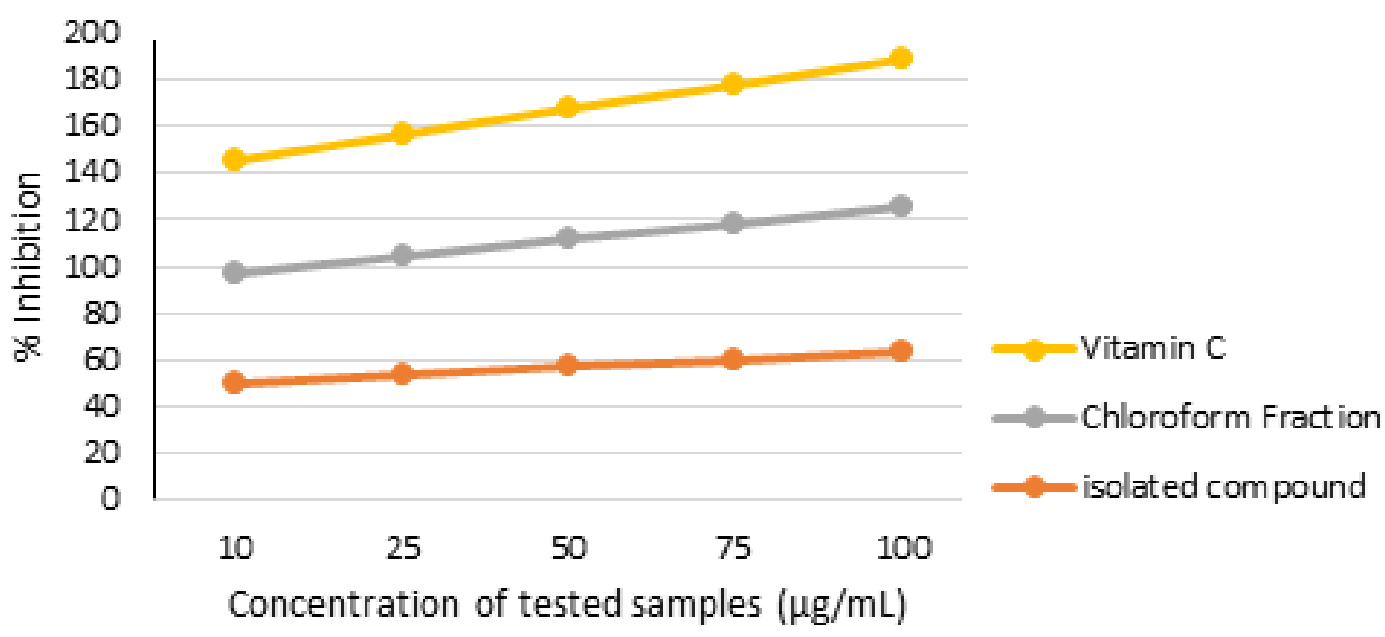

Figure 5. Comparison of percentage inhibition of isolated compound (gallic acid) from stem bark of $S$. littorale, chloroform fraction and vitamin C 
Table 2. Antioxidant activities of tested samples (chloroform fraction (CF), isolated compound (IC) from the stem bark of S. littorale and vitamin C (Vit. C)).

\begin{tabular}{ccc}
\hline $\begin{array}{c}\text { Tested } \\
\text { Samples }\end{array}$ & Linear Regression & $\begin{array}{c}\text { Antioxidant activity } \\
\left(\mathbf{I C}_{\mathbf{5 0}} \boldsymbol{\mu g} / \mathbf{m L}\right)^{\mathbf{a}}\end{array}$ \\
\hline CF & $\mathrm{y}=0.1545 \mathrm{x}+46.421\left(\mathrm{R}^{2}=0.992\right)$ & 23.2 \\
IC & $\mathrm{y}=0.1528 \mathrm{x}+48.850\left(\mathrm{R}^{2}=0.993\right)$ & 7.5 \\
Vit. C & $\mathrm{y}=0.1570 \mathrm{x}+48.036\left(\mathrm{R}^{2}=0.991\right)$ & 12.5 \\
\hline
\end{tabular}

${ }^{\mathbf{a}}$ The antioxidant activity was evaluated as the concentration of the tested samples (CF, IC and Vit.C) required to decrease the absorbance at $515 \mathrm{~nm}$ by $50 \%$ in comparison to the control.

$$
\begin{array}{ll}
\mathrm{ROO}^{\bullet}+\mathrm{ArOH} & \rightarrow \mathrm{ROOH}+\mathrm{ArO}^{\bullet} \\
\mathrm{ROO}^{\bullet}+\mathrm{ArO}^{\bullet} & \rightarrow \text { non-radical products } \\
\mathrm{ArO}^{\bullet}+\mathrm{RH} & \rightarrow \text { chain-propagating species }
\end{array}
$$

Figure 6. The role of radical-scavenging antioxidants (e.g. ArOH) in an autoxidation inhibition process

Phenolic compounds are almost universally used for industrial/commercial applications as well as in nature. The compounds (called be $\mathrm{ArOH}$ ) possessing high reactivity properties may chain peroxyl radicals ( $\mathrm{ROO}^{\circ}$ ) to form hydrogen peroxide derivative (ROOH). The mechanism of the reaction displaying the formal transfer of an $\mathrm{H}$-atom from the $\mathrm{ArOH}$ to the peroxyl radical $\left(\mathrm{ROO}^{\circ}\right)$ can be shown at reaction 1 (Figure 6).

Peroxyl radical (ROO'), then can react with phenoxyl radical $\left(\mathrm{ArO}^{\circ}\right)$ to produce a non-radical products (reaction 2 in Figure 6). According to Valgimigli et al., 2013), under some circumstances such as when diffusion of the antioxidant is impeded, and it has limited opportunity to encounter other radical species, it is possible for the antioxidant-derived phenoxyl radical to propagate the chain reaction reaction 3 (Figure 6).

However, data obtained from the present study suggest that chloroform fraction of stem bark of the plant might depend on the antioxidant properties. These results showed that the possible therapeutic potential of the stem bark of the plant may depend on the antioxidant properties exerted by their phenolic contents. These antioxidant properties could be attributed to the gallic acid (isolated compound) from chloroform fraction of this plant. Nowadays, we still continue investigating the other phenolic compounds and their antioxidant activity of the fraction and the other fractions of the plant, beside to $S$. polycephalum, $S$. polyanthum, and $S$. malaccensis.

\section{CONCLUSION}

A phenolic compound isolated from the chloroform fraction of stem bark of $S$. littorale have been determined as gallic acid. The compound is found for the first time from the chloroform fraction of the stem bark of $S$. littorale., although it has previously been found in other Syzygium species such as $S$. aromaticum, S. cumini, $S$. polyanthum, $S$. cordatum, etc. Antioxidant activity of isolated compound ( $\mathrm{IC}_{50}$ value of $7.5 \mu \mathrm{g} / \mathrm{mL}$ ) is more active than that of vitamin $\mathrm{C}$ as standard $\left(\mathrm{IC}_{50}\right.$ value of $12.5 \mu \mathrm{g} / \mathrm{mL}$ ).

\section{ACKNOWLEDGEMENTS}

We wish to thank Directorate of Research and Innovation Empowerment, Directorate of Empowerment for Research and Development, the Ministry of Research, Technology and High Education, for financial support to our 
project in the FUNDAMENTAL RESEARCH Schema-2016 (Grant Number: 294/UN38/HK/LT/2016, March 1, 2016). Also, deeply thanks to Hyiya Amen for help us to measure NMR.

\section{REFERENCES}

Alma, M. H., Murat, E.,Siegfrie, N.,\& Hubert, K. (2007). Chemical composition and content of essential oil from the bud of cultivated Turkish clove (Syzygiumaromaticum). Ncsu,edu/BioResources, 2(2), 265-269.

Ariyanti, E. E., Rony, I., Lia, H., \&Deden, M. (2012). Distribution of Syzygium spp. (klampok) in some areas of Bromo Tengger Semeru National Park, East Java. Proceeding of Society Indonesian Biodiversity International Conference, 1, 135142.

Braca, A.,Tommasi, N.D., Bari, L.D., Pizza, C.,Politi, M., \& Morelli, I. (2001). Antioxidant principles from Bauhinia terapotensis. Journal of Natural Products, 64(7), 892-895.

Har, L.-W., \& Ismail, I.S. (2012). Antioxidant activity, total phenolics and total flavonoid of Syzygiumpolyanthum (Wight) Walpleaves. Int. J. Med. Arom. Plants,2(2), 219-228.

Hiranrat, Asadhawut (2010). Chemical constituents from Rhodomyrtustomentosa (Aiton) Hassk and antibacterial activity, Thesis, Copyright of Prince of Songkla University.

Khan, R.A., Khan, M.R., Sahreen, S., \& Ahmed, M. (2012). Evaluation of phenolic contents and antioxidant activity of various solvent extracts of Sonchusasper (L.) Hill. Chemistry Central Journal, 6(12), 1-7.doi: 10.1186/1752-153X-6-12.

Komuraiah, B., Srinivas, C., Niranjana, A.K., K.V.N.S.,Srinivas, K.V.N.S., Venu, C., Kumar, J.K., Sastry, \& Paramjit, G. (2014). Isolation of phytochemicals from anticancer active extracts of Syzygiumalternifolium Walp. leaf. Phcog J., 6(4), 83-85. doi: 10.5530/pj.2014.4.13.

Manaharan, T., David, A., Hwee, M.C., \& Uma, D.P. (2012). Flavonoids isolated from from Syzygiumaqueum leaf extract as potential antihyperglycaemic agents. Food Chemistry, 132, 1802-1807. doi:

10.1016/j.foodchem.2011.11.147.

Muthumperumal, C., Nadarajan, S., Arun, K.D., \& Swamy, P.S. (2016). Chemical profiling of leaf essential oil, antioxidant potential and antibacterial activity of Syzygiumlanceolatum (Lam.) Wt. \&Arn. (Myrtaceae). Free Radicals and Antioxidants, 6(1), 13-22. doi: 10.5530/fra.2016.1.2.

Osman, H., Afidah, A.R., Norhafizah M.I., \& Nornaemah, M. B. (2009). Antioxidant activity and phenolic content of Paederiafoetida and Syzygiumaqueum, Molecules, 14, 970-978. doi:10.3390/molecules14030970.

Patrick-Iwuanyanwu, K.C., Onyeike, E.N., \& Adhikari, A. (2014). Isolation, identification and characterization of gallic acid derivatives from leaves of Tapinanthusbangwensis. Journal of Natural Products, 7, 14-19.

Reynertson, Kurt Allerslev. (2007). Phytochemical analysis of bioactive constituents from edible Myrtaceae fruits. A Dissertation Submitted to the Graduate Faculty in Biology in partial fulfillment of the requirements for the Degree of Doctor of Philosophy, The City University of New York.

Ruan, Z.P., Liang, L.Z., \& Yi, M.L. (2008). Evaluation of the antioxidant activity of Syzygiumcumini leaves. Molecules, 
13, 2545-2556.doi: 10.3390/ molecules 13102545 .

Sikder, Md. Al Amin, Mohammad, A.K., Mohammad, S.R., Choudhury, M.H., Adnan J. Al-R.,\& Mohammad, A.R. (2012). Secondary metabolites from seed extracts of Syzygiumcumini(L.), Journalof Physical Science, 23(1), 83-87.
Valgimigli, L., Bartolomei, D., Amorati, R., Evan Haidasz, E., Hanthorn, J.J., Nara, S.J., Brinkhorst, J., \& Pratt, D.A. (2013). 3-Pyridinols and 5pyrimidinols: tailor-made for use in synergistic radical-trapping coantioxidant systems. Beilstein Journal of Organic Chemistry, 9, 2781-2792.doi: 10.3762/bjoc.9.313. 